\title{
Dominican Party System Continuity amid Regional Transformations: Economic Policy, Clientelism, and Migration Flows
}

\author{
Jana Morgan \\ University of Tennessee \\ 1001 McClung Tower \\ Knoxville, TN 37996-0410 \\ Phone: 865.748 .8145 \\ janamorgan@utk.edu \\ Jonathan Hartlyn \\ University of North Carolina at Chapel Hill \\ hartlyn@unc.edu \\ Rosario Espinal \\ Temple University \\ espinal@temple.edu
}

The definitive version was published in Latin American Politics and Society, 53 (1): 1-32. www.wiley.com/bw/journal.asp?ref=1531-426X\%20

\begin{abstract}
In the 1980s and 1990s, economic crisis produced ideological convergence in many Latin American party systems. Much scholarship explores how this convergence frequently provoked system change that enabled renewed ideological differentiation, but little research examines instances where convergence has persisted without destabilizing the system. Through comparative historical analysis of Dominican continuity amid regional change, we identify factors that sustain or challenge party systems. Then through analysis of Americas Barometer surveys, we assess the causal mechanisms through which these factors shape public support for the traditional Dominican parties. We demonstrate that maintaining programmatic and clientelist linkages facilitates system continuity. In addition, we argue that the threats political outsiders pose to existing party systems are constrained when people excluded from the system are divided and demobilized. In the Dominican case, Haitian immigration divides the popular sector while Dominicans abroad sustain ties to the parties, with both migration flows facilitating party system continuity.
\end{abstract}


Over the past decade, party politics in Latin America have been characterized by considerable change and upheaval (Dietz and Myers 2007; Roberts 2003; Tanaka 1998). Throughout the region, parties experienced policy convergence in the neoliberal era of the $1980 \mathrm{~s}$ and 1990s, and instability has especially plagued party systems without ideological differences (Gutierrez 2007; Mayorga 2005; Morgan 2007). Eventually, the social restructuring that accompanied neoliberalism produced pressures for renewed programmatic alternatives in many countries. Party system responses to these pressures have varied. In some countries like Mexico and Uruguay, new ideological options emerged or grew without challenging the party system, facilitating adaptation and system survival (Greene 2007; Luna 2007). But in Venezuela, Bolivia, and Peru, party systems have experienced great turmoil as challengers threatened the traditional systems.

While many countries have experienced the sometimes traumatic effects of increased demand for ideological differentiation, other party systems in the region, like those in the Dominican Republic, Costa Rica and Panama, have persisted remarkably unchanged despite the absence of perceived programmatic options for voters. Party systems in the region that lacked programmatic differentiation during the neoliberal era can be divided into roughly three groups based on their subsequent evolution: those in which all the governing parties were discredited and now provide renewed ideological differentiation following dramatic upheaval; those in which opposition parties emerged or grew within the system, enabling programmatic differences to develop through gradual adaptation in party system structure; and those that still manifest ideological convergence but remain relatively stable. Table 1 uses data from the 2008 Americas Barometer surveys to depict the ideological placements the major parties' supporters in several 
Latin American party systems, providing examples each of these three types. ${ }^{1}$ As expected, only the first two groups demonstrate significant differences in the ideological placement of people who identify with each system's major parties. ${ }^{2}$

\section{INSERT TABLE 1 ABOUT HERE}

A growing body of scholarship seeks to explain the phenomena of party system upheaval and adaptive change, with considerable research focused on countries like Bolivia, Venezuela and Mexico (Barr 2005; Dietz and Myers 2007; Greene 2007; Luna 2007; Morgan 2007). But few efforts have been made to determine if cases of continuity in party system structure are consistent with theories that focus on instances of change. A complete explanation of party system dynamics should account not only for instances of dramatic change or adaptation, but should also apply where systems have been relatively stable (Mahoney and Goertz 2004). In this article, we evaluate existing theories of change and adaptation by assessing their ability to offer convincing accounts of continuity. We provide a general framework to explain both change and stability, detailing the specific causal mechanisms that are especially relevant in the Dominican context.

\section{Continuity despite Ideological Convergence: The Dominican Party System}

Given these objectives, we move beyond the more frequently studied patterns of upheaval and adaptation in party systems and focus our analysis on stability in party system structure despite a lack of ideological options. The cases of system continuity that are most

\footnotetext{
${ }^{1}$ The Americas Barometers, conducted by LAPOP across the western hemisphere using face-toface interviews, are national probability samples of voting-age adults.

${ }^{2}$ In Group 1, neither the current governing nor major opposition parties existed when the democratic transition took place, and significant left-right differentiation exists. In Group 2, traditional parties remain but important new parties have entered the system, and significant ideological differentiation is present. In Group 3, the same major parties have remained influential since the transition, but there is no ideological differentiation. This typology is not meant to be exhaustive, but illustrative of several major possibilities.
} 
germane are those that share theoretically relevant features with cases that have been the locus of previous scholarship about party system change. Because neoliberal reform and social restructuring are frequently seen as significant factors contributing to party system change (Barr 2005; Coppedge 2001; Levitsky 2003; Morgan n.d.; Roberts 2003), we are most interested in cases of continuity where systems have sustained ideological uniformity around neoliberal consensus despite high social costs. ${ }^{3}$

The Dominican Republic satisfies each of these features and contradicts regional trends of party system change. The Dominican party system is one of the few current systems in the region with a stable structure. The three parties that dominated politics after the 1978 democratic transition remain major players, and although there have been important realignments among the parties, the system's basic structure remains intact. In the 2008 Americas Barometer survey, 70 percent of Dominicans reported that they sympathized with a party, by far the highest rate in the region (Morgan and Espinal 2009)

While the major Dominican parties initially offered ideological options, these distinctions moderated over time. In the late 1970s and 1980s, the PLD (Dominican Liberation Party) carried the mantle of the left, but in the late 1990s, it emerged as the dominant actor representing conservative elements of society, joining the formerly center-left PRD (Dominican Revolutionary Party) and the historically conservative PRSC (Social Christian Reformist Party) on the right. Now no party appeals to the 25 percent of Dominicans who locate themselves on the left (Morgan and Espinal 2009).

At the same time, the Dominican Republic experienced crisis-induced neoliberal reforms. Similarly, the country followed regional patterns of increasing poverty and unemployment and

\footnotetext{
${ }^{3}$ We follow Mahoney and Goertz (2004) in selecting the Dominican Republic.
} 
declining wages. ${ }^{4}$ But the parties did not decay in the face of these changes. No party or leader has emerged to threaten the party system status quo. Instead, the popular sector remains politically weak and the traditional parties remain dominant. In contrast to countries like Bolivia, Colombia, and Venezuela where traditional parties also experienced ideological convergence, the Dominican system has not experienced collapse or dramatic reconfiguration.

How has the Dominican party system remained largely intact despite challenges like ideological convergence, economic crisis and social problems - all factors that have played a role in destabilizing party systems elsewhere in Latin America? This is the central question we explore in this article. In the next section, we expound our theoretical expectations by developing and applying claims found in the existing literature to the Dominican case. We then test whether our hypotheses are borne out empirically, using survey data to assess the motivations for Dominicans' partisan commitments. Finally, we explore our arguments' general applicability through regional comparisons.

\section{Explaining Party System Stability amid Regional Transformations}

Based on the comparative literature, we identify four factors that may promote party system stability in a context like the Dominican Republic. First, because positive perceptions of economic performance allow governing parties to credit-claim, lack of sustained crisis and periods of economic recovery have enabled Dominican parties to avoid the decay in support that often results from perceived unresponsiveness. Second, the clientelist exchanges that the Dominican parties supply provide a reserve of support that facilitates continuity. Third, popular sector fragmentation, which in the Dominican context is caused by Haitian immigration and disenfranchisement of poor, dark-skinned Dominicans and Dominico-Haitians, minimizes the

\footnotetext{
${ }^{4}$ Data from Banco Central de la República Dominicana and World Bank (1995; 2001).
} 
destabilizing effects of social ills like increased poverty and inequality that have undermined other party systems in the region. Fourth, given the features of Dominican emigration, the transnational activities of Dominicans abroad and the remittances they send home both promote continuity.

\section{Economic Policy Linkage despite Ideological Convergence}

A common theme in the literature on party system stability versus change is the central role that the maintenance of linkage plays in shaping these outcomes. Linkage refers to the various strategies parties use to connect society to the state, allowing for the exchange of support and influence (Lawson 1980; Morgan n.d.). A system that provides linkage is likely to survive. But where linkage fails, party systems change (Lawson 1988). In part, the stability of the Dominican system may be explained by linkage-based theories. One important source of linkage is programmatic representation, which furnishes universal public goods via either ideological options or policy responsiveness (Kelly 2003; Kitschelt 2000; Luna 2008; Mainwaring and Torcal 2006). We argue that comparatively strong economic growth and stability in the country has enabled some governing parties to claim valence policy responsiveness, thereby fostering public support despite a lack of ideological options.

As in many other Latin American party systems in the 1980s and 1990s, the Dominican parties converged around a neoliberal consensus in response to the debt crisis and international pressures toward market reforms. First the center-left PRD migrated toward the right, as PRD president Salvador Jorge Blanco (1982-86) governed at the height of the crisis and was forced to renege on campaign promises and carry out painful economic reforms (Espinal 1987). Then, over the late 1990s, the PLD, which had once been the farthest left party, also moved right. By the 1996 elections, a political pact between Joaquín Balaguer (PRSC) and the formerly left- 
leaning PLD largely erased any remaining ideological distinctions among the three parties. All converged on the center-right, and Dominicans lost the opportunity to express discontent with the status quo through the party system, posing a challenge to programmatic linkage.

But even in a context of economic crisis and reduced ideological differentiation, parties that avoid a sustained downturn and oversee renewed economic gains may avoid losing support and instead take credit for recovery. By claiming credit for a turnaround, parties in government offer believable policy responses such as economic growth or recovery, which appeal to people across the political spectrum, thereby mitigating the effects of the crisis on the party system. Positive evaluations of economic performance reflect positively on the incumbent (though not necessarily the opposition), bolstering support for the party and promoting system continuity (Remmer 1991; Roberts 2003).

In the Dominican case, the country experienced comparatively brief crisis periods, ${ }^{5}$ and there were some economic gains, which enabled the PRSC in the early 1990s and then the PLD in 2004-08 to claim policy success by tackling this salient issue. After the onset of crisis in the mid-1980s, the economy recovered fairly quickly. Inflation stabilized by 1992, and between 1990 and 2001, GDP per capita increased 51\%, a record surpassed in the region only by Chile (Espinal, Hartlyn and Kelly 2006; IADB 2001). Although the country experienced another downturn in 2003-04, the decline was again temporary, only discrediting the governing PRD, but not threatening the entire system.

With this experience of abbreviated crisis followed by recovery, the absence of alternatives to the center-right consensus was less threatening to programmatic linkage in the

\footnotetext{
${ }^{5}$ The main crisis years were 1983-4, 1988-90, \& 2003-4. The PRD governed in 1983-4 \& 200304. The PRSC governed in the late 1980s, but Balaguer narrowly won re-election in 1990 and subsequently benefited from recovery.
} 
Dominican context because at least one traditional party could credibly promise and successfully achieve resolution of the country's economic problems. Fundamental macroeconomic problems like devaluation and inflation were resolved by parties pursuing pro-market policies, reducing pressure for alternatives to the center-right consensus. Even when the incumbent party fared poorly in an election due to a declining economy, as in 1986 and 2004, this did not impact the party system as a whole.

Unlike some countries where crisis and neoliberal reforms were followed by sustained economic and social deterioration that discredited the entire party system, more abbreviated crises that largely weakened the PRD, as well as positive economic performance under the PRSC and the PLD, have facilitated the provision of some policy-based linkage in the Dominican Republic. We therefore hypothesize that Dominicans who view the economy favorably are likely to be pleased with the government's performance on this valence policy issue, and as a result, they will be supportive of the incumbent party. In the empirical analysis we present below, we use people's sociotropic evaluations of the economy to test whether successful economic performance attracts partisans to the traditional parties, particularly the incumbent PLD. ${ }^{6}$

Additionally, although we expect ideological linkage within the party system to be constrained to those who place themselves on the right side of the spectrum, this form of programmatic appeal may be important in promoting support for the traditional parties at least among that portion of the population. Thus, we also incorporate a measure of ideology, expecting respondents who place themselves on the right to support one of the major parties, while those on the left are likely to avoid traditional party affiliation. ${ }^{7}$

\footnotetext{
${ }^{6}$ Economic evaluations are a 5-point scale based on the item: “¿Cómo calificaría la situación económica del país?" Higher scores denote more positive evaluations.

${ }^{7}$ We measure ideology with the same 10-point left to right scale as in Table 1.
} 


\section{Shoring up the Clientelist Base Conserves the Status Quo}

Party systems that maintain a stream of clientelist benefits in exchange for votes possess a stabilizing reserve of support, whereas those unable to deliver sufficient material benefits to satisfy demand lose electoral appeal (Kitschelt 2000; Levitsky 2007; Piattoni 2001). In the Dominican Republic, the state has had a clientelist, patrimonial nature at least since the lengthy period of authoritarianism under Rafael Trujillo (1930-61) (Hartlyn 1998). And unlike some Latin American countries where parties have recently seen their clientelist capacity decay (Birnir and Van Cott 2007; Luna 2007; Mayorga 2005), the Dominican parties, all of which embrace clientelist strategies, have been able to sustain clientelism. Many Dominicans who seek clientelist linkage are likely to have their demands met. Therefore, we hypothesize that clientelism encourages support for the traditional parties, protecting the party system status quo.

Several factors facilitate the preservation of exchange-based linkage strategies in the Dominican Republic, helping sustain traditional party ties. Maintaining clientelism essentially requires that parties have sufficient resources to satisfy demand for direct benefits (Magaloni et al. 2007; Piattoni 2001). In the Dominican context, poverty, inequality and disenfranchisement have inhibited increases in clientelist demand, while economic recovery and clientelist access to the public sector have enabled the parties to sustain benefits. As a result, clientelism has remained integral to system stability.

Inequality and poverty combined with low levels of popular sector organization facilitate clientelist linkage by allowing parties to satisfy immediate needs at little cost, because they can offer inexpensive, individual benefits in exchange for votes (Magaloni et al. 2007). In the Dominican Republic, high poverty rates enable the parties to extend small clientelist benefits to the poor, who still constitute more than 60 percent of the population (Morillo et al. 2005), while 
also providing targeted benefits to middle-sector partisans. Furthermore, inequality allows parties to diversify their linkage portfolio, offering clientelist exchanges to the poor and economic policy responsiveness to the educated and wealthy for whom clientelism is insufficient (Levitsky 2007; Luna 2008). ${ }^{8}$

Moreover, the lack of identity cards needed to vote remains widespread among the poor, including descendants of Haitian immigrants, and this disenfranchisement limits their ability to pressure for benefits (Duryea, Olgiati and Stone 2006; PNUD 2007). Without identity papers, many of the poor are barred from the political process. The parties can afford to ignore the disenfranchised, reducing the pressure on their clientelist networks. Because few efforts have been made to register these potential voters, the parties do not have to worry about reaching out to new clients. On this dimension, the Dominican experience stands in contrast with other countries like Bolivia, Ecuador and Venezuela where extensive registration and mobilization campaigns among the poor expanded the electorate and multiplied pressures for clientelist benefits (Mayorga 2005; Penfold-Becerra 2007; Van Cott 2005).

In addition to poverty, inequality and disenfranchisement moderating increases in clientelist demand, the parties have been able to sustain an adequate supply of resources. Although the Dominican Republic was affected by the 1980s debt crisis and the global economic downturn in the early 2000s, on the whole the country's economy has fared relatively well. Foreign exchange from tourism and remittances has cushioned the effects of these shocks, and the economy has recovered quickly, experiencing some of the highest growth rates in the region (Espinal, Hartlyn and Kelly 2006; PNUD 2005; World Bank 2001). Thus, these downturns have not devastated state finances, assuring the parties' access to state resources and preserving

\footnotetext{
${ }^{8}$ The Gini coefficient in the Dominican Republic from the late 1990s through 2004 has hovered around .52, and the 90-10 ratio has been about 10 (World Bank 2006b).
} 
clientelist benefit flows. While other Latin American parties governed in countries suffering from debt and fiscal constraints, the Dominican growth trajectory has helped to protect resources for clientelism.

The parties have also been able to guard access to public resources, which they channel into their clientelist networks. Public employment, an important source of patronage, remained at nearly 12 percent of the economically active population in 1998 (Baker 1997; ONE 2003; Sánchez-Fung 2000). In fact over the 1980s, Dominican governments nearly doubled the number of people on the public payroll, protecting this patronage resource (Baker 1997, 97; SánchezFung 2000). ${ }^{9}$ This pattern contrasts with the experience of neighboring countries where public employment rolls were reduced under neoliberalism. In Jamaica for instance, government jobs declined by $30 \%$ in the 1980s (Baker 1997: 95), in Brazil public employment in the 1990s fell to 9\% of the economically active, and in Peru it dropped to 7\% (Murrillo 2001). The Dominican parties also created new avenues for accessing state funds. Party and campaign finance measures of 1997, which overwhelmingly direct revenues to the major parties, increased the state resources available to the parties for clientelist distribution (Hartlyn and Espinal 2009). By protecting old clientelist resources and developing new forms of financing, the parties preserved their access to the funds they need to feed their clientelist machines.

In sum, the literature on clientelist linkage suggests that maintaining such ties should help stabilize the party system, and the Dominican parties have not faced the same challenges to their clientelist machines that some of their neighbors have encountered. We hypothesize that Dominicans who seek or benefit from some form of clientelism are likely to support one of the traditional parties, especially the governing party which has the greatest capacity to distribute

\footnotetext{
${ }^{9}$ Less than $20 \%$ of Dominican public employees hold university degrees, suggesting that many are filling jobs offered as clientelist favors (Sánchez-Fung 2000).
} 
benefits.

To test this expectation in our analysis below, we include two measures tapping different aspects of clientelism. First, because public employment is a major source of patronage, we include a dummy variable for public employees. Many who work for the state obtain their jobs through clientelist connections, and we expect them to support the major parties, especially the incumbent PLD which likely provided them with their job. Second, to capture a broader range of exchange-based activities, we include an item that asks whether respondents sought state or partisan assistance in resolving a personal or community problem. ${ }^{10}$ Such individualized problem-solving by politicians is frequently conducted with the aim of promoting partisan ties. Those who seek politicized assistance, therefore, are more likely to support one of the traditional parties than to be independent.

\section{Migration and Disenfranchisement Counteract Potentially Destabilizing Change}

Shifts in social structure, like escalating poverty, unemployment and informality that tend to accompany neoliberal reforms, pose threats to party system stability (Burgess and Levitsky 2003; Morgan n.d; Roberts 2003). As a party system's traditional base erodes and is replaced by new, unrepresented interests, group-based ties to existing parties weaken. If they disintegrate, this can destabilize the party system (Piattoni 2001). However, such upheavals only become politically relevant for party system dynamics when excluded groups are not exceptionally fragmented but instead are fairly unified and mobilized against the status quo (Roberts 2002; Van Cott 2005). If new group identities do not form to threaten old linkage patterns and social changes remain depoliticized, the system is likely to remain stable (Lipset and Rokkan 1967;

\footnotetext{
${ }^{10}$ This variable is based on principal-component factor analysis of three items: “Para poder resolver sus problemas alguna vez ha pedido Ud. ayuda o cooperación 1) A algún diputado del Congreso? 2) A alguna autoridad local? 3) A algún secretario, institución pública, u oficina del estado?" Higher scores indicate more efforts to solicit assistance.
} 
Piattoni 2001). The Dominican case is a clear instance of social change having a limited impact on the party system because excluded interests are divided and demobilized.

Like much of Latin America, the Dominican Republic underwent a massive socioeconomic transformation in the second half of the $20^{\text {th }}$ century. From a largely rural country reliant on sugar exports, the country has become predominantly urban, with a globalized economy based on trade, tourism and remittances. This transformation was spurred by changes in the world economy, economic crisis, pressure from international financial institutions, and domestic policy change. Attendant to these economic changes were social displacements that swelled the ranks of the poor and unemployed in the 1980s and 1990s. However, in contrast to the experiences of regional neighbors like Bolivia and Venezuela, where similar social transformations spelled party system upheaval, the Dominican party system to date has remained surprisingly stable.

In the Dominican Republic, the excluded popular sector is neither unified nor mobilized and therefore does not present a challenge to the party system. Fragmentation of excluded groups minimizes the political impact of socioeconomic restructuring and the party system persists unchallenged. Factors such as ethnic divisions, disenfranchisement, or civil war may fragment excluded groups and diminish their political relevance. In the Dominican context, we argue that the primary mechanisms producing this result are patterns of racially and nationally charged conflict surrounding Haitian immigration and the disenfranchisement of Dominico-Haitians. ${ }^{11}$ These patterns undermine the political influence of the popular sector, allowing for sustained exclusion of poorer, darker segments of the population without harmful repercussions for the

${ }^{11}$ Due to political rhetoric, "Dominico-Haitiano" has been largely replaced by the phrase "dominicanos descendientes de haitianos." Both terms refer to individuals of Haitian descent born in the Dominican Republic For simplicity, we use Dominico-Haitian. 
party system.

We are not arguing that simply having a large immigrant population inherently creates fragmentation. But in the Dominican case, the relative magnitude of the Haitian and DominicoHaitian populations as well as the long-standing, racially-charged conflict and exclusion surrounding this migration flow creates a popular sector that is sharply divided and hard to organize, helping sustain the party system.

Haitian migration into the Dominican Republic has generated significant Haitian and Dominico-Haitian populations, who tend to work in difficult low-wage, low-skill jobs (Moya Pons 1986). The Haitian-born population is comprised of a large group of long-term residents and a smaller temporary population. Pervasive lack of documentation among these groups makes it difficult to know their exact size. But one 2003 estimate provides low, middle, and high figures of 115,000, 417,000 and 833,000 (PNUD 2006, 125), making undocumented Haitians as much as $8 \%$ of the Dominican population. Additionally, Haitian authorities estimate that DominicoHaitians, who are born in the Dominican Republic with one or two Haitian parents, number about 280,000 , or approximately $5 \%$ of the voting age population (Ferguson 2003). Together Haitian migrants and Dominico-Haitians probably constitute about $10 \%$ of the population.

From a comparative perspective, this migrant group is particularly large and significant. Of the other Latin American countries for which data are available, only Costa Rica, with about $10 \%$ of its population being foreign-born, mostly from Nicaragua, approaches the Dominican level of inward migration (UN 2009). Costa Rica also joins the Dominican Republic as one of the few countries that has maintained a relatively stable party system despite the parties' ideological convergence, at least through 2008 (Table 1). Additionally, in the 2006 Americas Barometer conducted in 20 Latin American countries, the highest intent to emigrate was found in 
Haiti: $65 \%$ of those surveyed said they planned to migrate within the next three years, with many presumably crossing into the Dominican Republic (Hiskey and Montalvo 2008). No other country reached $50 \%$ who intended to emigrate (e.g. in Nicaragua, only $20 \%$ intended to migrate), suggesting unmatched migration pressures on the Dominican Republic (Ferguson 2003).

But even more important than the relative size of the Haitian migration flow is the historically-embedded and racially-motivated conflict between Dominicans and Haitians (be they foreign-born or Dominican-born). This deeply-rooted divide, which is reinforced by the systematic and legal exclusion of undocumented Haitians and Dominico-Haitians, fosters the fragmentation of the popular sector between darker-skinned Haitians and their Dominican counterparts, minimizing their political relevance.

Haitian immigration has taken place in a context of distrust, prejudice, and exploitation. Building on a history of Haiti's invasion and occupation of the Dominican part of the island in the $19^{\text {th }}$ century, a brutal massacre of Haitians on the border in 1937, and Trujillo's efforts to construct Dominican identity as juxtaposed against Haiti, a culture of entrenched prejudice against Haitians exists in the Dominican Republic (Howard 2001; Moya Pons 1993). While most Dominico-Haitians speak Spanish in their homes and identify as Dominicans, they also report facing racism and mistreatment based on their Haitian ancestry (Silié, Segura and Dore Cabral 2002). Dominican cultural attitudes remain strongly anti-Haitian (Morgan and Espinal 2009), and practices of segregation and intolerance perpetuate conflict surrounding national identity (Silié and Segura 2002). The history of conflict and ongoing prejudice against those of Haitian descent create an atmosphere of fear (Silié et al. 2002).

This atmosphere undermines the potential political impact that a unified popular sector 
might have. "Prejudice and racism - disguised as antihaitianismo ideology - distract attention from class and economic issues" (Sagás 2000,119). Race and nation have come to replace class as the leading influences in political discourse and in the formation of group identity (Howard 2001, 155). As a result, anti-Haitianism becomes an effective tool in the hands of the Dominican elite, enabling them to fragment and manipulate the popular sector using widely accepted discrimination (Sagás 2000). One event that exemplifies the way anti-Haitianism can be manipulated by the elite to influence politics was the 1994 presidential election (Ferguson 2003; Howard 2001; Sagás 2000). When it seemed that the dark-skinned José Francisco Peña Gómez (PRD) might win, his opponents made his Haitian ancestry a campaign issue and "implied that the country's identity, economic well-being - and even its very existence as a sovereign state would all be threatened by his victory" (Hartlyn 1998, 237).

Furthermore, those of Haitian ancestry face considerable obstacles to political participation, which limits any potential impact they might have on the party system and perpetuates the status quo from which they are systematically excluded. Undocumented Haitians are summarily denied political rights and have limited opportunities to obtain legal papers. Also, based on a particular interpretation of the old constitution, authorities have ignored international law and refused to provide Dominican citizenship to Dominico-Haitians born and raised in the country, which legally inhibits them from voting. ${ }^{12}$ This interpretation, which was upheld by the Supreme Court, affirms a long-held informal practice of denying birth certificates to children of undocumented parents, a problem especially common in border areas. ${ }^{13}$ And the new Dominican

\footnotetext{
${ }^{12}$ In 2005, the Inter-American Human Rights Court ruled that the practice of denying citizenship to children born to Haitian parents violated international treaties (IDH 2005).

${ }^{13}$ Undocumented Haitians were considered to be "in transit" (regardless of the amount of time they have been in the Dominican Republic), and thus their descendants were not given citizenship or identity papers. A 2004 migration law reinforced this interpretation.
} 
Constitution, which was promulgated in January 2010, explicitly prevents the children of undocumented Haitian immigrants from claiming Dominican citizenship. The political significance of denying citizenship to Dominico-Haitians is profound, as both Haitian immigrants and their offspring face the same fate of "illegality" and permanent exclusion.

The scope of this exclusion is notable. Based on demographic and health surveys, Duryea, Olgiati and Stone (2006) estimate that of six Latin American countries (Bolivia, Brazil, Colombia, Dominican Republic, Peru, Nicaragua), Dominican rates of under-registered births are the highest at $25.8 \%$. Unregistered births, which translate into lack of identity papers, affect poor Dominicans and Dominico-Haitians alike, but the provinces bordering Haiti are above the national average, with under-registration at almost $50 \%$ in one. The government seeks to perpetuate this practice of denying citizenship to Dominico-Haitians for political reasons, as they fear that relaxing existing procedures would stimulate Haitian migration and that giving citizenship to Dominico-Haitians would result in significant unpredictable changes in election results (Ferguson 2003, 22).

Together the fragmentation and demobilization of the popular sector created by antiHaitian sentiment and racially-motivated prejudices as well as the legal exclusion of DominicoHaitians and other poor Dominicans who lack identity papers minimize the political influence of the popular sector in the Dominican Republic. As a result, existing parties can ignore them, and they do not present an opportunity for political outsiders to cultivate support. Thus, we hypothesize that popular sector demobilization and explicit exclusion of Dominico-Haitians help stabilize the existing party system. Because no traditional party takes a pro-Haitian stand nor do they seek to stop racially-based prejudice, we do not expect the party system to reflect divisions along the issues of Haitian rights and discrimination, but instead we anticipate a lack of 
differences between party supporters and independents on these issues. In the empirical analysis, we include measures of support for Haitian rights and of the respondent's discrimination experiences. ${ }^{14}$ But because these issues neither polarize the parties nor stir up independents, we expect to find no significant effects for these variables in the analysis.

Additionally, we do not anticipate significant effects of race on partisanship. None of the traditional parties make race-based appeals, and most Dominicans, even those who are darkskinned and have African features, are reluctant to identify as black or mulatto. Instead, most Dominicans identify as having indigenous and/or white ancestry (68\%) (LAPOP 2008). Therefore, with the possible exception of the PRD, in which a black politician - Peña Gomez reached top leadership, we do not expect to observe significant differences in the racial composition of different partisan groupings.

\section{Dominicans Abroad Bolster the Traditional Parties}

We also consider how the transnational activities of the large Dominican community abroad may shape party system dynamics on the island. Some cross-national scholarship on emigration suggests that migrants are more likely to be dissatisfied with the status quo, which enables their exit to act as a safety valve alleviating pressure for change (Hiskey and Montalvo 2008). Alternatively, some parties look to migrants abroad for financial and other forms of support, which reinforces traditional partisan ties (Graham 1997; Guarnizo 1998; OstergaardNielsen 2003). In particular, the transnational activities of migrants from democracies on the periphery of the world economy, like the Dominican Republic, tend to reinforce rather than

\footnotetext{
${ }^{14}$ We tap support for Haitian rights with a factor score constructed from two questions: whether the children of Haitians born in the Dominican Republic should be given citizenship and whether undocumented Haitians should be given work permits. Higher values indicate more support for Haitians. To assess discrimination, we include a dummy variable based on the item: "¿Alguna vez se ha sentido discriminado o tratado de manera injusta por su apariencia física o su forma de hablar en lugares públicos?"
} 
challenge power structures in sending countries (Itzigsohn 2000).

This pattern of migrants abroad stabilizing the status quo is an especially likely outcome in the Dominican context where migrants' partisan ties have been significant for several decades and remain highly developed. As scholars of transnational political practices suggest, the nature and impact of such activism varies considerably and is especially influenced by "contexts of exit and reception" (Portes 2003, 879). Therefore, we are not asserting that emigration and transnational practices are necessarily similar, much less inherently stabilizing. But they are likely to have this effect in the Dominican Republic, where migration emerged in a framework of strong party ties that remain important. We hypothesize that the nature of Dominican emigration enhances the likelihood that migration and remittances stabilize the party system (Duany 2004; Graham 1997; Itzigsohn 2000; Portes et al. 2007; Sagás 2004).

In the Dominican case, emigration has been highly politicized and rooted in strong party ties since the exit began in earnest in the 1960s. Under the Balaguer regime (1966-78), outmigration was facilitated by both Dominican and U.S. policy. The first major wave of migration was largely political in nature, motivated by the turmoil of the 1960s and facilitated by U.S. occupation of the Dominican Republic (Grasmuck and Pessar 1991; Mitchell 1992; TorresSaillant and Hernández 1998). Dissidents who feared persecution under Balaguer fled and gained relatively easy access to North American soil as the U.S. government collaborated with Dominican elites to help stabilize a friendly conservative regime (Duany 2004; Itzigsohn 2000). Once in the U.S., opposition parties began organizing there, and New York became a locus for Dominican party development (Itzigsohn 2000; Sagás 2004). At the same time, U.S. support for conservative leadership in the Dominican Republic led to a significant setback for the left, contributing to a rightward list in the party system. The PRD's eventual defeat of Balaguer in 
1978 was clearly facilitated by the party's shift away from the left. Overall, the historical context of U.S.-Dominican relations helps us understand the conservative evolution of the Dominican party system and the nature of ties between Dominican parties and migrants.

The political character of the early waves of Dominican migration continues to shape the patterns of transnational activism in this migrant community (Portes et al. 2007). Furthermore, Dominican migrants gained the right of dual nationality in 1994, and the overseas vote in 1997, promoting their ongoing investment in party politics at home (Foner 2005; Sagás 2004). As the migrant population has grown, U.S. branches of the Dominican parties have played an increasingly important role in "financing political activities and mobilizing support" (Graham 1997; Itzigsohn 2000, 1132). Presidential candidates frequently make fund-raising trips to New York and San Juan (Duany 2004, 42). For instance in the 1994 election, Peña Gómez made 7 trips to New York in 13 months, raising hundreds of thousands of dollars, while Balaguer accessed remittances through the Dominican consulates (Sagás 2004, 58) ${ }^{15}$ In a phone survey of Dominicans in the Washington Heights neighborhood of New York City, 20\% said they had been engaged in some form of transnational partisan activity, more than the rates of participation in other forms of transnational involvement (Pantoja 2005).

Dominicans living abroad are also more engaged in support of traditional party politics than their counterparts from the rest of Latin America. Considerable comparative research supports the view of the Dominican migrant community as unusually engaged in home country party politics. Dominicans in the U.S. were far more likely to engage in party politics at home than Colombians, Salvadorans, Mexicans and Haitians (Guarnizo, Portes and Haller 2003; Itzigsohn 2000; Portes et al. 2007; Shain 1999). In a survey of 90 transnational organizations in

${ }^{15}$ Since the 1997 initiation of public financing, the centrality of migrant funds has waned. 
the Dominican, Colombian and Salvadoran communities in the United States, Portes and his coauthors (2007) found that the PRD in New York had the largest reported membership, whereas Mexican migrants showed almost no transnational political participation. The limited transnational partisan activity of Mexican migrants is relatively recent and on a much smaller scale than in the Dominican community (Fussell 2004; Smith 2003). Even the Salvadoran migrant community, which shares some features with the Dominican diaspora, is less politically active. El Salvador is the only Latin American country with an overseas population that rivals the Dominican as a proportion of their domestic populations, ${ }^{16}$ and in both early migration flows were politically motivated. However, the Salvadoran FMLN has focused on building its organization at home, and migrants lack trust in domestic institutions (Itzigsohn 2000). These patterns have led to a less significant role for parties among Salvadoran migrants than among Dominicans, for whom parties are central transnational organizations.

In light of the original political motivations of out-migration, sustained participation in transnational partisan activities, and parties with an active presence in the Dominican migrant community, Dominicans abroad involved with their home country are especially likely to be engaged in party politics (see Levitt 2001b). Also, given the strong ties that migrants have with both the PRD and the PLD, we expect that when Dominicans abroad influence domestic politics, they are likely to support these parties.

We assess migrant influence on the party system through financial ties to the island. ${ }^{17}$ Concomitant with Dominican out-migration has been growth in remittances to family members at home. Remittances are estimated at US\$2.7 billion per year - about 14\% of GDP (World Bank

\footnotetext{
${ }^{16}$ Salvadorans and Dominicans abroad are estimated to equal about $20 \%$ of the population at home (Andrade 2006; Bendixen [2004] quoted in World Bank 2006). Ecuador is the only other country that comes close, with $10-15 \%$ abroad (Jokisch 2007).

${ }^{17}$ Ideally we could measure migrants' party ties directly, but we do not have such data.
} 
2006, 98) and constitute the country's largest source of foreign exchange (Shain 1999). Based on the 2002 census, the UNDP estimated that remittances reached $10.2 \%$ of all Dominican households, and on average the funds equaled $30 \%$ of these households' income. Other figures are much higher, estimating that as many as $38 \%$ of Dominican adults receive remittances regularly (Duany 2008; World Bank 2006). The scope of Dominican remittances becomes clear when placed in regional perspective. In the 2008 Americas Barometer, $19 \%$ of Dominicans reported receiving remittances. Only four countries had significantly higher rates: El Salvador $27 \%$, Haiti $-49 \%$, Jamaica $-40 \%$, and Guyana $-35 \%$. Dominican per capita remittance flows are the fourth highest in the region, after Jamaica, Guyana and El Salvador (Duany 2008).

Given Dominican migrants' documented support of the traditional parties, it follows that those receiving remittances from abroad would hold similar attitudes. Also, remittances strengthen the economic situation for those who receive them and for the nation as a whole (Durand, Parrado and Massey 1996; Guarnizo 2003; Smith 2003). Thus, we argue that the transmission of remittances may bolster the traditional parties by promoting support for migrants' political goals, providing resources for campaigns, and limiting individual remittancerecipients' desire to mobilize against the status quo (Graham 1997; Guarnizo 1998; Levitt 2001a; Shain 1999). Due to the historical evolution of Dominican migration, we expect that those who receive remittances will be more likely to support a major party, especially the PRD or PLD, than to be independents. ${ }^{18}$

\section{Dominican Party System Stability: Multivariate Analysis}

To test our hypotheses concerning the factors that promote party system stability in the Dominican Republic, we analyze why Dominicans support one of the three parties in the existing

\footnotetext{
${ }^{18}$ To measure receipt of remittances, we use the item: “¿Ud. o alguien que vive en su casa recibe remesas (dinero) del exterior?"
} 
system as opposed to being independent. Public support for the traditional parties is a pivotal element in the system's stability. By exploring the micro-level underpinnings of party system continuity, we gain insight into why citizens continue to support the major Dominican parties, stabilizing the status quo. Specifically, we analyze Dominicans' partisanship in the 2008 Americas Barometer survey (LAPOP 2008). ${ }^{19}$ We also engage in supplementary analysis of the 2006 LAPOP and 2004 DEMOS surveys. ${ }^{20}$

Based on the hypotheses detailed above, we examine four major sets of variables in explaining Dominican partisanship. We include measures of 1) ideology and economic evaluations to assess the effects of ideological and valence programmatic linkages; 2) public employment and seeking partisan assistance to resolve personal problems to test the influence of clientelism; 3) support for Haitian rights, experiences of discrimination, and race to examine the impact of social fragmentation; and 4) remittance receipts to test the influence of migrants abroad. Our theoretical discussion above leads us to expect that right ideology, positive economic evaluations, public employment, seeking assistance, and receiving remittances increase support for the traditional parties. Meanwhile, we anticipate that the social fragmentation created by nationally and racially charged Haitian immigration will translate into little to no party system effect for Haitian rights, discrimination, and race. Since no party advocates for Haitian rights even though the plight of Haitians is highly publicized and no party speaks against racial discrimination, we do not expect these factors to have any impact on party politics at all. We also include education, sex, urban residence, income and religiosity as control

\footnotetext{
${ }^{19}$ To measure partisanship, we employ two questions: “¿En este momento, simpatiza con algún partido político?" and “¿Con cuál partido político simpatiza usted?” Those who do not sympathize with a party are coded as Independents. Remaining respondents are coded according to the party they report sympathizing with.

${ }^{20}$ All three Dominican surveys use national probability samples of voting-age adults with faceto-face interviews. Samples are stratified by region and urban versus rural residence.
} 
variables.

\section{Discussion of Findings}

To test these hypotheses, we use multinomial logit analysis to compare people who identify with each of the three major parties - PRD, PLD and PRSC - to people who do not hold partisan ties. ${ }^{21}$ An initial examination of the findings in Table 2 demonstrates that the analysis supports our expectations. ${ }^{22}$ But because logit coefficients are not easily interpreted, we calculate simulated predicted probabilities using Clarify (King, Toms, and Wittenberg 2001). These probabilities are presented in Table 3 for all the significant findings. The scores tell us the change in the probability of a respondent belonging to the associated category of the dependent

${ }^{21}$ To avoid potential pitfalls associated with missing data, we used AMELIA (King, Honaker, and Scheve 2001) to impute missing values. Multiple imputation overcomes the problems of bias, inefficiency and incorrect standard errors that result from dropping all cases with missing data. AMELIA applies an algorithm to existing data to assign values to variables where respondents did not provide an answer, creating five versions of imputed data, which are essentially averaged in the logit analysis. AMELIA assumes that "the pattern of missingness only depends on the observed data...not the unobserved" (Honaker, King and Blackwell 2009, 4). As is typical when conducting multiple imputation, we must assume it is possible to assign values using the observed data. To make this assumption plausible, we include a large number of variables (84) in imputing missing data so that we have as much information as possible when assigning values (Honaker et al. 2009). The amount of information incorporated in the imputation makes it reasonable to assume that the observed data are adequate to impute missing values, and by using imputation, we avoid results that over-represent respondents with complete data or that produce biased standard errors. The main variable with missing data was ideology, with about $22 \%$ missing. Income also had $16 \%$ missing. On the other variables, the number of missing values was negligible. When we conducted an alternative analysis without imputation and just dropped cases with missing data, we found essentially the same substantive results as those depicted in Table 2. Imputation eliminates possible problems of bias and inefficiency, and in practice it did not alter the substantive results.

${ }^{22}$ A likelihood ratio test indicates strong goodness of fit. The model in Table 2 performs significantly better than the null. We conducted the same analysis with 2006 LAPOP data, which produced very similar results. In both years, Independents are less likely than party sympathizers to find programmatic or clientelist linkage. They are less likely to be on the right, to evaluate the economy positively, to be public employees, and to seek clientelism. They are also less likely to get remittances. The only differences were that in 2006 seeking partisan assistance was only significant for the PLD, remittances were significant for the PRSC instead of the PRD, and identifying as black had no effect. For the full results consult: http://web.utk.edu/ kellyjm/papers/papers.html. 
variable when moving from the lowest to highest observed score on the independent variable of interest, holding all other variables held to their appropriate measure of central tendency. Table 3 helps us discern not only a variable's statistical significance but also the size of its effect on partisanship. $^{23}$

\section{INSERT TABLES 2 AND 3 ABOUT HERE}

As anticipated, right ideology dominates the party system. Independents position themselves significantly to the left of the traditional right party, PRSC, and the former left option, PLD. The ideological divide between independents and PLD partisans is large - being on the far right increases the probability of PLD support by 26 points, a notable change. ${ }^{24}$ These findings indicate that those on the right are likely to find ideological linkage through the existing parties, while those on the left are not. As the data in Table 1 also suggested, ideological differences are not an important element of the party system.

But ideological differentiation is not the only programmatic strategy that parties may use in appealing to voters. We have also hypothesized that policy responsiveness, measured using positive economic evaluations, fosters support for the party system, especially the incumbent party. The analysis bears out this expectation. In fact, the positive influence of economic evaluations on support for the PLD is the single largest effect. Although other variables have substantively important influences on partisanship, moving from very negative to very positive perceptions of economic performance increases the likelihood of affiliation with the PLD by 68 percentage points. Meanwhile, people with negative assessments of the economy are much more likely to affiliate with the PRD, which is the major opposition party, or be independents.

\footnotetext{
${ }^{23}$ A table with descriptive statistics for all the variables is available at the above website.

${ }^{24}$ The different ideologies of PRD and PLD observed in Table 1 remain significant in the multivariate context, but the divide is small. In essence, all the parties appeal to the right.
} 
Effective economic policy responsiveness has bolstered the continuity of the Dominican party system. ${ }^{25}$

The analysis also confirms that clientelism contributes to stabilizing the system. Public employees are prone to be recipients of patronage given the politicization of the Dominican state and are, thus, much more likely to support the governing PLD than to be independents. Being a public employee increases the probability of supporting the PLD by almost 20 points. Patronage through public employment has a substantively important effect, stabilizing the status quo. ${ }^{26}$ Additionally, respondents who sought help from a party or state official in Congress, local government, or the national bureaucracy were significantly more likely to support the PLD, PRD or PRSC than to be independent. The effects here are not as large as that of public employment, but seeking partisan assistance decreases the probability of being independent by .16. This form of clientelism helps all the existing parties, suggesting that they each build support through exchange-based ties. This is not an inconsequential effect, particularly when we consider that this variable is a crude measure of the underlying concept of clientelist exchange. Between the public employment and seeking partisan assistance variables, it is clear that clientelism remains an important form of linkage that benefits the traditional parties.

Additionally, the analysis shows that the transnational actions of Dominicans abroad reinforce the traditional party system. Early Dominican migrants sought to escape political repression under Trujillo and Balaguer, exiled PLD and PRD leaders built U.S. organizations,

${ }^{25}$ Analysis of the 2006 LAPOP and 2004 DEMOS supports this finding, with positive economic evaluations boosting support for incumbents (PLD in 2006 and PRD in 2004). Amid the 2004 economic crisis, fewer people had positive assessments (2\%) than in $2006(13 \%)$ or $2008(17 \%)$. But even then, positive evaluations increased incumbent support.

${ }^{26}$ The multivariate analysis provides an estimate for the effect of public employment while controlling for any possible indirect relationship public employment might have via economic evaluations. Empirically, the correlation between these two variables is small, .08, indicating that any such indirect effect is negligible. 
and later migrants connected to these pre-existing political networks. Given these politicized features of Dominican migration flows, we expect a positive relationship between remittances and support for the existing parties. In the analysis, we find that respondents who receive remittances are more likely to support the PLD or the PRD. Those who do not receive remittances are $13 \%$ more likely to be independents, while Dominicans who do benefit from this source of income tend to support the PLD, with a probability increase of .09, or the PRD, with a probability increase of .04. Emigration from the Dominican Republic and migrants' ongoing partisan ties provide not only financial but also popular support to the parties, promoting system survival.

We also hypothesized that nationally and racially charged conflict surrounding Haitian immigration into the Dominican Republic undermines the unity of the popular sector and inhibits efforts at mobilization around a new political movement, which could destabilize the party system. The disenfranchisement of Dominico-Haitians pushes them out of the Dominican political system entirely, while also creating popular sector divisions. Both patterns support the status quo by limiting challenges to the major parties. The issues of Haitian rights and racial discrimination are not politicized cleavages that mobilize sectors of the Dominican electorate; indeed they are not reflected at all in the party system, as all the major parties advocate similar, anti-Haitian stances. The "Haitian issue" is not a cleavage dividing supporters of the major parties. Moreover, given the way Dominican national identity has been built in opposition to Haiti, neither is it a latent issue that distinguishes independents from partisans. Because Haitian migration remains an issue that unites all "true" Dominicans and undermines the formation of class identity, we do not expect any significant differences across partisans and independents on the issues of Haitian rights and exposure to discrimination. The analysis supports our 
expectations. We find no significant differences in partisanship between those who have faced discrimination and those who have not. Level of support for Haitian rights also has no significant effect, indicating that these issues are not politicized within the Dominican party system and also do not distinguish independents from partisans.

The only party that has historically shown any willingness or ability to attract support based on these largely silent issues of race and nation is the PRD. Being black increases the probability of backing the PRD by .07. With the black Dominico-Haitian Peña Gómez at the helm of the PRD from the mid-1970s until his death in 1998, this party built up some support among the small proportion of Dominicans who identify as black (18\% in the survey). But even the PRD has not attempted to politicize racial discrimination or Haitian rights, opting instead to attract a small amount of support through racial identity while preserving the status quo by explicitly avoiding a pro-Haitian stance. Because of the way race and the Haitian issue are intertwined, it is extremely difficult for a party to mobilize supporters around these concerns without creating internal party problems as well as uncontrollable fissures which could threaten all the parties. Therefore, the parties remain united in their support for constraining citizenship for Dominico-Haitians and in their concerns about Haitian migration.

\section{Conclusions: Linkage, Fragmentation and Remittances as Party System Stabilizers}

We have assessed the extent to which accounts of party system change and collapse also provide insight into cases where systems have remained stable despite a lack of ideological differentiation between parties, highlighting the specific causal mechanisms at work in the Dominican context. The analysis indicates that theories of party system change also help explain continuity. Despite an absence of ideological options, the Dominican parties have managed to sustain some programmatic linkage through economic policy responsiveness, particularly by the 
governing PLD. Dominicans who evaluated the economy positively were much more likely to support the incumbent party, stabilizing the status quo. This finding reiterates what previous scholarship has found concerning neoliberal reforms, namely that the extent or nature of the reforms themselves do not directly determine party dynamics, rather it is government's success or failure in alleviating the crisis that shapes party support. Additionally, the parties' ability to sustain the flow of clientelist benefits has provided a steady base of support among public employees and other partisan clients. Despite the problems exchange-based linkage might pose for the quality of representation and accountability, clientelism helps to sustain parties, as long as resources are sufficient to meet demand.

Together these findings concerning programmatic and clientelist appeals support previous research that emphasizes the significance of linkage maintenance for party system survival, or alternatively linkage decay for system change or collapse (Kitschelt 2000; Lawson 1988; Levitsky 2007; Morgan n.d.). Scholarship on party and system decay emphasizes how parties' inability to sustain linkage opened doors to their opponents. For instance, the traditional parties in Uruguay lost their capacity to satisfy escalating demand for material exchanges, which provided an opportunity for the growth of Frente Amplio (Luna 2007). In Venezuela, the parties allowed programmatic, corporatist and clientelist linkages to fail, giving Hugo Chávez a foothold in the once-stable polity (Burgess and Levitsky 2003; Morgan 2007; n.d.). And in Bolivia, the traditional parties converged around neoliberalism and saw their clientelist resources fall short of demand, which contributed to Evo Morales' rise to power (Barr 2005; Birnir and Van Cott 2007). Alternatively, the Dominican parties' ability to sustain linkage through both policy responsiveness and clientelism promotes system stability. The scholarship on party system change together with our insights concerning Dominican stability indicates that maintaining 
linkage is crucial for party system collapse, adaptation, and continuity.

We also explored the theoretical insight that the manner in which social structure is translated into the political system has profound implications for the relationship between social change and party system dynamics. In countries like Bolivia, Ecuador and Venezuela, where economically and ethnically excluded groups have become unified and politicized, the party systems have experienced major convulsions (Barr 2005; Roberts 2003; Van Cott 2005). But in countries like the Dominican Republic where excluded sectors are fragmented and demobilized, these groups are much less likely to destabilize the party system.

In the Dominican context, the popular sector is divided by racially and nationally charged conflict surrounding issues of Haitian immigration and citizenship. These schisms complicate creation of a broad coalition among the poor and facilitate the parties' focus on delivering limited clientelist benefits only to the smaller group of enfranchised poor without facing electoral repercussions for ignoring Haitian immigrants, their descendants and other disenfranchised Dominicans. Our empirical analysis supports these claims. We found no differences between party sympathizers and independents in their support for Haitians' rights or their experiences with discrimination. These issues do not divide the parties, and independents are not calling for some party to take pro-Haitian or anti-discrimination positions. Instead, anti-Haitian rhetoric unites Dominicans regardless of social class or partisanship, limiting the opportunity for political outsiders to mobilize an electoral threat to the party system built on a coalition of excluded sectors.

We are not arguing that immigration patterns are necessary for fragmentation, nor that immigration inherently creates fragmentation. Rather in some contexts, like the especially fractious Haitian-Dominican dynamic, immigration may serve as a causal mechanism creating 
division among excluded sectors, which minimizes the likelihood that their continued exclusion will undermine the party system. Popular sector fragmentation also seems to have protected the stability of other Latin American party systems that lack ideological differentiation. Table 1 identified two other systems that follow this pattern of stability despite ideological uniformity in 2008: Costa Rica and Panama. In both, the popular sector is significantly divided and/or demobilized. Several factors may generate this division and demobilization, but in both cases, immigration patterns appear to contribute. Costa Rica has attracted many Nicaraguans who migrated seeking economic opportunity and escaping the turmoil created by their country's civil war. Nicaraguan immigrants have tended to fill lower paying jobs in agriculture, construction, and informal retail, competing with poor Costa Ricans. As a result of this immigration flow, relations between Costa Rica and Nicaragua have been strained, and anti-Nicaraguan sentiment is widespread (Mahler and Ugrina 2006). Earlier immigrants from the West Indies into Costa Rica's Puerto Limón region also maintain a separate identity, further dividing society (Maingot 1994). Panama has a similar enclave of West Indian and other migrants in the Canal Zone, and these migration flows, together with more recent pressures from Colombians seeking asylum, have contributed to popular sector fragmentation in Panama as well (Mahler and Ugrina 2006; Maingot 1994). Of course, immigration is not the only factor that may divide and demobilize excluded sectors; several causal mechanisms may promote these outcomes. In Panama, for instance, analysts have emphasized how the concentration of poverty among the indigenous population creates a dual exclusion based on poverty and ethnicity, which exacerbates the political irrelevance of these groups (Pérez 2008).

Finally, we have identified how the particular nature of Dominican exit migration promotes system continuity. Significant Dominican migration began in a highly politicized 
context, and both the PRD and PLD built party organizations in the United States, away from the repressive reach of Trujillo and Balaguer. Subsequent Dominican migrants entered alreadypoliticized networks in support of these parties, making the Dominican community abroad one of the most active in transnational party politics. Our analysis confirms that Dominican migrants' engagement with their home country promotes party system stability. The Dominican case stands out in this regard because of the uniquely politicized and partisan nature of the Dominican migrant community. Additional research will be required to explore the party system effects in other contexts where this relationship between migrants and the parties at home is also found.

In sum, this paper identifies general factors that promote party system stability and then specifies and provides empirical evidence in support of the ways in which they have operated in the Dominican context. In general, sustaining programmatic and clientelist linkage bolsters support for the traditional system, and a fragmented, demobilized popular sector makes it difficult for potential challengers to emerge and threaten the existing party system. Furthermore, in the Dominican context, the nature of exit migration provides additional support for the traditional parties. Future threats to economic policy success and clientelist benefit provision might undermine linkage in the Dominican system. Likewise, popular sector mobilization and unification that somehow overcomes racist and nationalist conflict would pose an ominous hurdle for the party system to navigate. But for now, linkage maintenance, fragmentation of the poor, and loyal support from Dominicans abroad enable this conservative, ideologically undifferentiated party system to persist. 


\begin{tabular}{|c|c|c|c|}
\hline Country & Party $^{\mathrm{a}}$ & $\begin{array}{c}\text { Mean } \\
\text { Ideology }\end{array}$ & $\begin{array}{c}\text { Significant Party } \\
\text { Differences }\end{array}$ \\
\hline \multicolumn{4}{|c|}{ Systems that Experienced Structural Upheaval and Ideological Differentiation } \\
\hline \multirow[t]{3}{*}{ Bolivia } & MAS & 4.00 & \multirow{3}{*}{$\begin{array}{l}\text { MAS-MNR } \\
\text { MAS-PODEMOS }\end{array}$} \\
\hline & MNR & 7.41 & \\
\hline & PODEMOS & 6.38 & \\
\hline \multirow[t]{5}{*}{ Colombia } & Partido Liberal & 7.07 & \multirow{5}{*}{$\begin{array}{l}\text { PL-PD } \\
\text { PC-PD } \\
\text { PD-PUN } \\
\text { PD-CR }\end{array}$} \\
\hline & Partido Conservador & 6.65 & \\
\hline & Polo Democrático & 3.62 & \\
\hline & Partido de la Unidad Nacional & 7.21 & \\
\hline & Cambio Radical & 7.71 & \\
\hline \multirow[t]{4}{*}{ Venezuela } & MVR & 5.62 & \multirow{4}{*}{$\begin{array}{l}\text { MVR-PSUV } \\
\text { MVR-UNT } \\
\text { PSUV-UNT } \\
\text { PSUV-PJ }\end{array}$} \\
\hline & PSUV & 3.19 & \\
\hline & UNT & 7.61 & \\
\hline & PJ & 6.54 & \\
\hline \multicolumn{4}{|c|}{ Systems that Underwent Adaptation in Structure and Ideological Differentiation } \\
\hline \multirow[t]{3}{*}{ Mexico } & PAN & 6.88 & \multirow{3}{*}{$\begin{array}{l}\text { PRD-PAN } \\
\text { PRD-PRI }\end{array}$} \\
\hline & PRI & 6.56 & \\
\hline & PRD & 4.90 & \\
\hline \multirow[t]{3}{*}{ Uruguay } & Frente Amplio & 3.26 & \multirow{3}{*}{$\begin{array}{l}\text { FA-PN } \\
\text { FA-PC }\end{array}$} \\
\hline & Partido Nacional & 7.47 & \\
\hline & Partido Colorado & 8.02 & \\
\hline Relatively Stab & System Structures without Id & ological D & fferentiation \\
\hline \multirow[t]{3}{*}{ Dominican Republic } & PRD & 6.49 & \multirow{3}{*}{ PRD-PLD } \\
\hline & PLD & 7.57 & \\
\hline & PRSC & 7.06 & \\
\hline \multirow[t]{3}{*}{ Costa Rica } & PUSC & 6.98 & \multirow{3}{*}{ PLN-PAC } \\
\hline & PLN & 7.35 & \\
\hline & PAC & 6.00 & \\
\hline \multirow[t]{3}{*}{ Panama } & PRD & 6.14 & \multirow{3}{*}{ None } \\
\hline & Arnulfista/Panameñista & 5.73 & \\
\hline & Partido Cambio Democrático & 6.01 & \\
\hline \multicolumn{4}{|c|}{$\begin{array}{l}\text { Note: } 2008 \text { Americas Barometer data by LAPOP, using anova and Bonferroni scores. } \\
\text { Ideology is measured on a } 10 \text {-point scale, } 1=\text { left and } 10=\text { right. Parties on left in bold. } \\
\text { a Only parties with more than } 20 \text { supporters are included in the table. }\end{array}$} \\
\hline
\end{tabular}




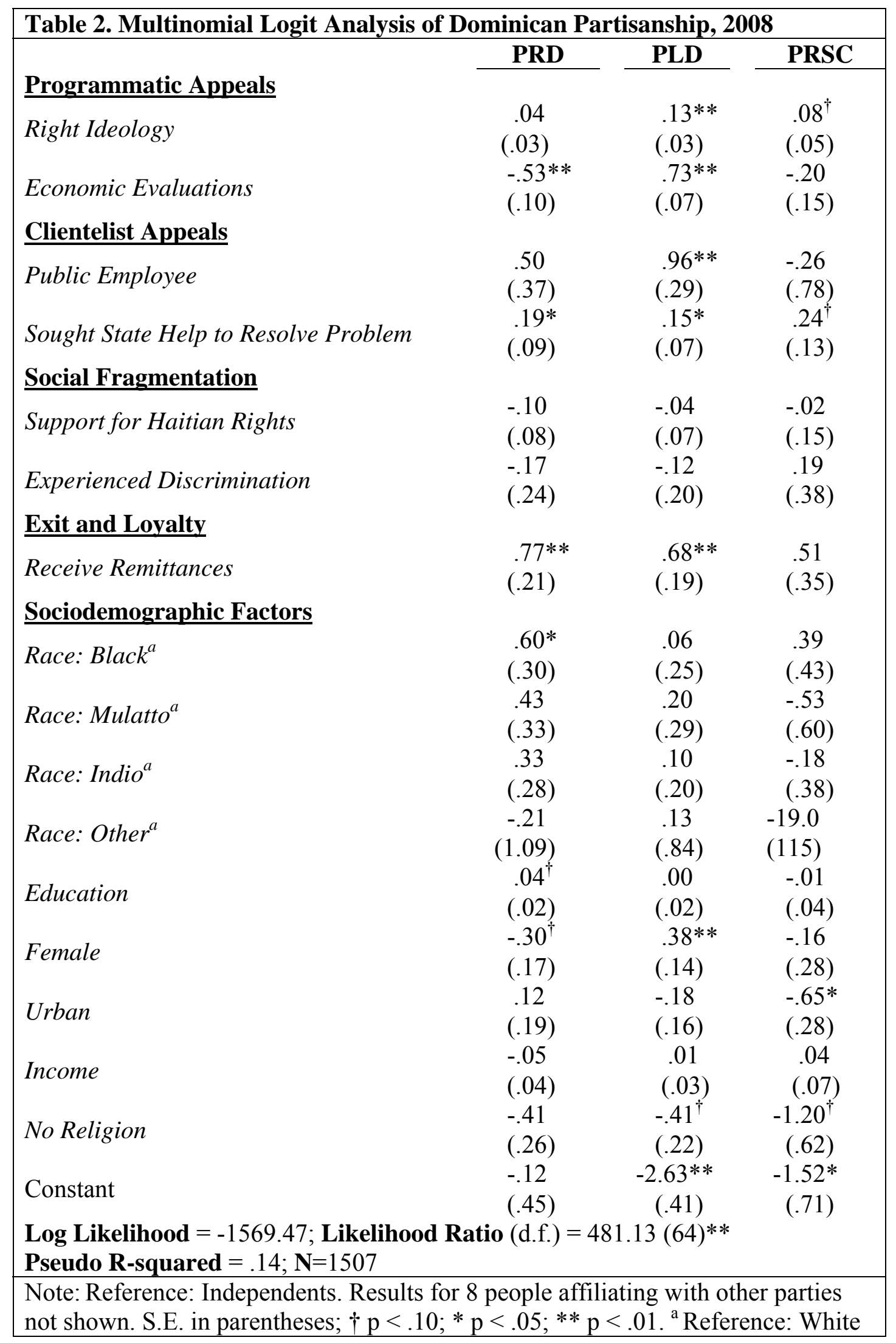




\begin{tabular}{|c|c|c|c|c|}
\hline & Independents & $\underline{\text { PRD }}$ & $\underline{\text { PLD }}$ & $\underline{\text { PRSC }}$ \\
\hline \multicolumn{5}{|l|}{ Programmatic Appeals } \\
\hline Right Ideology & -.23 & $--^{a}$ & .26 & .01 \\
\hline Economic Evaluations & -.31 & -.32 & .68 & -- \\
\hline \multicolumn{5}{|l|}{$\underline{\text { Clientelist Appeals }}$} \\
\hline Public Employee & -.16 & -- & .19 & -- \\
\hline Sought Help to Resolve Problem & -.16 & .06 & .08 & .03 \\
\hline \multicolumn{5}{|l|}{ Exit and Loyalty } \\
\hline Receive Remittances & -.13 & .04 & .09 & -- \\
\hline \multicolumn{5}{|l|}{ Sociodemographic Factors } \\
\hline Race: Black $^{b}$ & -.05 & .07 & -- & -- \\
\hline Education & -.02 & .09 & -- & -- \\
\hline Female & -.04 & -.06 & .12 & -- \\
\hline Urban & .04 & -- & -- & -.02 \\
\hline No Religion & .10 & -- & -.07 & -.02 \\
\hline \multicolumn{5}{|c|}{$\begin{array}{l}\text { Note: Only those effects shown to be significant in the multinomial logit analysis } \\
\text { presented in the previous table are reported here. Cell values represent change in the } \\
\text { probability of belonging to the relevant group when moving from the minimum to the } \\
\text { maximum value on the relevant independent variable with all other independent variables } \\
\text { set to their appropriate measures of central tendency. } \\
\text { a Not Significant }{ }^{\text {b }} \text { Reference Group: White }\end{array}$} \\
\hline
\end{tabular}




\section{References}

Andrade-Eekhoff, Katharine. 2006. "Migration and Development in El Salvador: Ideals versus Reality" Migration Information Source. Accessed 10 January 2010. http://www.migrationinformation.org/feature/display.cfm?ID=387

Baker, Judy L. 1997. Poverty Reduction and Human Development in the Caribbean: A Cross-Country Study. Washington, DC: World Bank, Discusión Paper No. 366.

Barr, Robert R. 2005. "Bolivia: Another Uncompleted Revolution” Latin American Politics and Society. 47 (3): 69-90.

Birnir, Jóhanna Kristin, and Donna Lee Van Cott. 2007. "Disunity in Diversity: Party System Fragmentation and the Dynamic Effect of Ethnic Heterogeneity on Latin American Legislatures" Latin American Research Review 42 (1): 99-125.

Burgess, Katrina and Steven Levitsky. 2003. "Populist Party Adaptation in Latin America: Environmental and Organizational Determinants of Party Change in Argentina, Mexico, Peru and Venezuela" Comparative Political Studies 36(8): 881911.

Coppedge, Michael. 2001. "Political Darwinism in Latin America's Lost Decade" in Larry Diamond and Richard Gunther (eds.) Political Parties and Democracy. Baltimore, MD: Johns Hopkins University Press, pp. 173-205.

Dietz, Henry A. and David J. Myers. 2007. "From Thaw to Deluge: Party System Collapse in Venezuela and Peru," Latin American Politics and Society 49 (2): 59-86.

Duany, Jorge. 2008. "Migration and Remittances in Puerto Rico, the Dominican Republic, and Mexico" Presented at Migration in the Americas: Mexico and Latin America in Comparative Context, May 4-6, 2008.

Duany, Jorge. 2004. "Los Países: Transnational Migration from the Dominican Republic to the United States" In E. Sagás and S.E. Molina, eds., Dominican Migration: Transnational Perspectives. Gainesville: University Press of Florida, pp. 29-52.

Durand, Jorge, E.A. Parrado, and D.S. Massey. 1996. "Migradollars and Development: A Reconsideration of the Mexican case" International Migration Review 30(2): 423-44.

Duryea, Suzanne, Analia Olgiati and Leslie Stone. 2006. "The Under-Registration of Births in Latin America." Washington DC: IADB, Working Paper \#551, January.

Espinal, Rosario. 1987. Autoritarismo y democracia en la política dominicana. San José: Centro Interamericano de Asesoría y Promoción Electoral, IIDH.

Espinal, Rosario, Jonathan Hartlyn and Jana Morgan Kelly. 2006. "Performance Still Matters: Explaining Trust in Government in the Dominican Republic" Comparative Political Studies 39 (2): 200-23.

Ferguson, James. 2003. "Migration in the Caribbean: Haiti, the Dominican Republic and Beyond." London: Minority Rights Group International.

Foner, Nancy. 2005. In a New Land: A Comparative View of Immigration. New York: New York University Press.

Fussell, Elizabeth. 2004. "Sources of Mexico's Migration Stream: Rural, Urban, and Border Migrants to the United States" Social Forces 82(3): 937-67.

Graham, Pamela. 1997. "Re-Imagining the Nation and Defining the District: The Simultaneous Political Incorporation of Dominican Transnational Migrants." Chapel Hill: Ph.D. diss., University of North Carolina at Chapel Hill.

Grasmuck, Sherri, and Patricia Pessar. 1991. Between Two Islands: Dominican 
International Migration. Berkeley: University of California Press.

Greene, Kenneth F. 2007. Why Dominant Parties Lose: Mexico's Democratization in Comparative Perspective. New York: Cambridge University Press.

Guarnizo, Luis Eduardo. 2003. "The Economics of Transnational Living” International Migration Review. 37 (3): 666-99.

Guarnizo, Luis Eduardo. 1998. "The Rise of Transnational Social Formations: Mexican and Dominican State Responses to Transnational Migration" Political Power and Social Theory 12: 45-94.

Guarnizo, Luis Eduardo, Alejandro Portes and William Haller. 2003. "Assimilation and Transnationalism: Determinants of Transnational Political Action among Contemporary Migrants," American Journal of Sociology 108(May): 1211-48.

Hartlyn, Jonathan.1998. The Struggle for Democratic Politics in the Dominican Republic. Chapel Hill: University of North Carolina Press.

Hartlyn, Jonathan and Rosario Espinal. 2009. "The 2008 presidential election in the Dominican Republic,” Electoral Studies 28 (2): 333-36.

Hiskey, Jonathan, and Daniel Montalvo. 2008. "Democratization, System Performance and the 'Exit' Option in Latin America" Paper prepared for presentation at the Midwest Political Science Association Meeting, Chicago, April 3-6.

Honaker, James, Gary King, and Matthew Blackwell. 2009. "AMELIA II: A Program for Missing Data" http://gking.harvard.edu/amelia/docs/amelia.pdf Accessed 6 January 2010. November 16.

Howard, David. 2001. Coloring the Nation: Race and Ethnicity in the Dominican Republic. Boulder: Lynne Rienner.

IADB. 2001. Dominican Republic: Country paper. Washington, DC: IADB, July 21.

IDH. 2005. Caso de las Niñas Yean y Bosico vs. República Dominicana. Sentencia de 8 de septiembre de 2005. Serie C. No. 130.

Itzigsohn, José. 2000. "Immigration and the Boundaries of Citizenship: The Institutions of Immigrants' Political Transnationalism" International Migration Review 34 (4): $1126-54$.

Jokisch, Brad. 2007. "Ecuador: Diversity in Migration.” Migration Information Source. http://www.migrationinformation.org/USfocus/ Accessed 14 January 2010.

Kelly, Jana Morgan. 2003. "Counting on the Past or Investing in the Future? Economic and Political Accountability in Fujimori's Peru" The Journal of Politics 65(3): 86480.

King, Gary, Joseph Honaker, Anne Joseph, and Kenneth Scheve. 2001. "Analyzing Incomplete Political Science Data: An Alternative Algorithm for Multiple Imputation" American Political Science Review 95 (1): 49-69.

King, Gary, Michael Tomz, and Jason Wittenberg. 2000. "Making the Most of Statistical Analyses: Improving Interpretation and Presentation" American Journal of Political Science 44 (2): 347-61.

Kitschelt, Herbert. 2000. "Linkages Between Citizens and Politicians in Democratic Polities" Comparative Political Studies 33 (6/7): 845-79.

LAPOP. 2008. The Americas Barometer. Nashville: LAPOP.

Lawson, Kay, ed. 1980. Political Parties and Linkage: A Comparative Perspective. New Haven: Yale University Press.

Lawson, Kay. 1988. "When Linkage Fails" In When Parties Fail: Emerging Alternative 
Organizations, eds. K. Lawson and P. H. Merkl. Princeton: Princeton University. Levitsky, Steven. 2007. "From Populism to Clientelism: The Transformation of LaborBased Party Linkages in Latin America." In Herbert Kitschelt and Steven I. Wilkinson, eds. Patrons, Clients and Policies: Patterns of Democratic Accountability and Political Competition. New York: Cambridge University Press, pp. 206-26.

Levitt, Peggy. 2001a. "Transnational Migration: Taking Stock and Future Directions" Global Networks 1(3): 195-216.

Levitt, Peggy. 2001b. The Transnational Villagers. Berkeley: University of California.

Lipset, Seymour Martin, and Stein Rokkan. 1967. "Cleavage Structures, Party Systems, and Voter Alignments." In Party Systems and Voter Alignments: Cross-national Perspectives, eds. Seymour Martin Lipset and Stein Rokkan. New York: Free Press.

Luna, Juan Pablo. 2008. "A Lost Battle? Building Programmatic Party-Voter Linkages in Contemporary Latin America: A Comparative Analysis of Chile and Uruguay” In G. O'Donnell, J. S. Tulchin, and A. Varas, eds. New Voices in the Study of Democracy in Latin America. Washington, DC: Woodrow Wilson Center, pp. 153-218.

Luna, Juan Pablo. 2007. Frente Amplio and the Crafting of a Social Democratic Alternative in Uruguay" Latin American Politics and Society 49 (4): 1-30.

Mahoney, James, and Gary Goertz. 2004. "The Possibility Principle: Choosing Negative Cases in Comparative Research" American Political Science Review 98(4): 653-69.

Magaloni, Beatriz, Alberto Diaz-Cayeros, and Federico Estévez. 2007. "Clientelism and portfolio diversification: A Model of Electoral Investment with Applications to Mexico" In Herbert Kitschelt and Steven I. Wilkinson, eds. Patrons, Clients and Policies: Patterns of Democratic Accountability and Political Competition. New York: Cambridge University Press, pp. 182-205.

Mahler, Sarah J., and Dusan Ugrina. 2006. "Central America: Crossroads of the Americas” Migration Information Source. Accessed 15 January 2010. http://www.migrationinformation.org/Feature/display.cfm?ID=386

Maingot, Anthony P. 1994. "Review of Banana Fallout: Class, Color and Culture among West Indians in Costa Rica." International Migration Review 28(3): 602-3.

Mainwaring, Scott P., and Mariano Torcal. 2006. "Party System Institutionalization and Party System Theory after the Third Wave of Democratization" in Handbook of Party Politics, eds. R. S. Katz and W. J. Crotty. Thousand Oaks, CA: Sage, pp. 204-27.

Mayorga, René Antonio. 2005. "Bolivia's Democracy at the Crossroads" In F. Hagopian and S. P. Mainwaring, eds. The Third Wave of Democratization in Latin America: Advances and Setbacks. New York: Cambridge University Press, pp. 149-78.

Mitchell, Christopher. 1992. "U.S. Foreign Policy and Dominican Migration to the United States," in C Mitchell, ed. Western Hemisphere Immigration and United States Foreign Policy. University Park: Pennsylvania State University Press.

Morgan, Jana. 2007. "Partisanship during the Collapse of the Venezuelan Party System" Latin American Research Review 42 (1): 78-98.

Morgan, Jana. n.d. Bankrupt Representation and Party System Collapse. University Park: Penn State University Press. Forthcoming.

Morgan, Jana, and Rosario Espinal. 2009. Cultura Política de la Democracia en República Dominicana, 2008: El Impacto de Gobernabilidad. Nashville: USAID.

Morillo, P., A. Guerrero A. and Yasiris Alcántara R. 2005. Focalización de la pobreza en la República Dominicana 2005. Santo Domingo, DR: Secretariado Técnico de la 
Presidencia, Procesamiento especial de la ENFT del Banco Central.

Moya Pons, Frank. 1993. "Las Tres Fronteras: Introducción a la frontera DominicoHaitiana" In Wilfredo Lozano, ed. La Cuestión Haitiana en Santo Domingo. Santo Domingo: FLACSO/North-South Center Press, pp. 17-32.

Moya Pons, Frank. 1986. El batey: Estudio socioeconómico de los bateyes del consejo estatal del azúcar. Santo Domingo: Fondo para el Avance de las Ciencias Sociales.

Murillo, María Victoria. 2001. "Latin American Labor” In Jorge I. Dominguez and Michael Shifter, eds., Constructing Democratic Governance in Latin America. Baltimore: The Johns Hopkins University Press, pp. 100-17.

ONE. 2003. Encuesta Nacional de Fuerza de Trabajo/Octubre 2003. Santo Domingo: ONE. Downloaded from: http://onedatabase.indotel.net.do/ Accessed 19 June 2009.

Ostergaard-Nielsen, Eva. 2003. "The Politics of Migrants' Transnational Political Practices" International Migration Review 37(3): 760-86.

Pantoja, Adrian D. 2005. "Transnational Ties and Immigrant Political Incorporation: The Case of Dominicans in Washington Heights" International Migration 43(4): 123-46.

Penfold-Becerra, Michael. 2007. "Clientelism and Social Funds: Evidence from Chávez's Misiones" Latin American Politics and Society 49 (4): 63-84.

Pérez, Orlando J. 2008. Cultura política de la democracia en Panamá, 2008: El impacto de la gobernabilidad. Nashville: USAID.

Piattoni, Simona. 2001. "Clientelism, Interests, and Democratic Representation" In Clientelism, Interests, and Democratic Representation: The European Experience in Historical and Comparative Perspective, Simona Piattoni, ed. New York: Cambridge University Press, pp. 193-212.

PNUD. 2005. Informe Nacional de Desarrollo Humano, República Dominicana 2005. Hacia una inserción mundial incluyente y renovada. Santo Domingo: PNUD.

Portes, Alejandro. 2003. "Theoretical Convergencies and Empirical Evidence in the Study of Immigrant Transnationalism” International Migration Review 37(3): 87492.

Portes, Alejandro, Cristina Escobar, and Alexandria Walton Radford. 2007. "Immigrant Transnational Organizations and Development: A Comparative Study" International Migration Review 41(1): 242-81.

Remmer, Karen. 1991. "The Political Impact of Economic Crisis in Latin America in the 1980s." American Political Science Review 85: 777-800.

Roberts, Kenneth. 2003. "Social Correlates of Party System Demise and Populist Resurgence in Venezuela" Latin American Politics and Society 45(3): 35-57.

Roberts, Kenneth. 2002. "Social Inequalities without Class Cleavages in Latin America's Liberal Era" Studies in Comparative International Development 36(4): 3-33.

Sagás, Ernesto. 2000. Race and Politics in the Dominican Republic. Gainesville: University Press of Florida.

Sagás, Ernesto. 2004. "From Ausentes to Dual Nationals: The Incorporation of Transmigrants into Dominican Politics," in E. Sagás \& S.E. Molina, eds. Dominican Migration: Transnational Perspectives. Gainesville: University Press of Florida.

Sánchez-Fung, José R. 2000. "Employment and labor markets in the Dominican Republic: An overview of the literature" CEPAL Review 71 (August): 157-69.

Shain, Yossi. 1999. "The Mexican-American Diaspora's Impact on Mexico" Political Science Quarterly 114(4): 661-91. 
Silié, Rubén, Carlos Segura, and Carlos Dore Cabral. 2002. La nueva inmigración haitiana. Santo Domingo: FLACSO.

Silié, Rubén and Carlos Segura. 2002. Una isla para dos. Santo Domingo: FLACSO.

Smith, Michael Peter. 2003. "Transnationalism, the State, and the Extraterritorial Citizen" Politics and Society. 31(4): 467-502.

Tanaka, Martín. 1998. Los espejismos de la democracia. El colapso del sistema de partidos en el Perú, 1980-1995, en perspectiva comparada. Lima: IEP.

Torres-Saillant, Silvio, and Ramona Hernández. 1998. The Dominican Americans. Westport, Conn.: Greenwood.

UN (United Nations). 2009. "International Migrant Stock: The 2008 Revision" New York: United Nations. url: http://esa.un.org/migration/ Accessed 12 January 2010.

Van Cott, Donna Lee. 2005. From Movements to Parties in Latin America: The Evolution of Ethnic Politics. New York: Cambridge University Press.

World Bank. 2006. Dominican Republic: Country Economic Memorandum. Washington DC: World Bank, Report No. 35731-DO.

World Bank. 2006b. Dominican Republic Poverty assessment: Achieving More Pro-Poor Growth. Washington, DC: World Bank, Report No. 32422-DO.

World Bank. 2001. Dominican Republic Poverty Assessment: Poverty in a High Growth Economy (1986-2000). Washington, DC: World Bank, Report No. 21306-DO. 